\title{
The military dimension of a more Militant Russia ${ }^{\text {ז }}$
}

\author{
Julian Cooper ${ }^{\mathrm{a}, \mathrm{b}}$ \\ ${ }^{a}$ Centre for Russian, European and Eurasian Studies, University of Birmingham, UK \\ ${ }^{b}$ Stockholm International Peace Research Institute, Solna, Sweden
}

\begin{abstract}
The article analyses the development of the military dimension of Russia's economy over the past decade or more, including the significant growth of military expenditure and its principal driver, spending on the ambitious state armament programme to 2020. For the first time for almost twenty-five years Russia once again possesses capable armed forces. With greater economic and military strength Russia's leadership now feels able to be more assertive, even militant, on the world stage. These developments threaten to be constrained by the poor performance of the economy, facing the government with a policy challenge. However, for Russia and the main Western powers there can be no going back to the status quo ante.

(C) 2016 Non-profit partnership "Voprosy Ekonomiki”. Hosting by Elsevier B.V. All rights reserved.
\end{abstract}

JEL classification: F51, F52, H56, L64.

Keywords: Russia, economy, military expenditure, defence, sanctions, economic performance.

\section{Introduction}

There is no dispute that present-day Russia is a more assertive power than it was a few years ago. This assertiveness and willingness to stand firm in the face of Western criticism and sanctions has become especially evident since the onset of the crisis and conflict over Ukraine. However, it could be argued that this turn to a more assertive, indeed militant, stance began before 2014. Perhaps the Ukraine crisis simply served to accentuate a trend of development that was already present. This article explores the issue by looking in some detail at the military dimension of what can be termed Militant Russia.

\footnotetext{
th An abbreviated version of this article was published in Russian as: Cooper J. The military face of "Militant Russia”. Rossiya v Globalnoi Politike, 2015, Vol. 13, No. 6, pp. 92-100.

E-mail address: j.m.cooper@bham.ac.uk.

Peer review under responsibility of Voprosy Ekonomiki.
} 


\section{The rapid growth of military spending}

A good starting point is to explore the changing priority of the military in Russia as manifested in the resource commitment to its development, from late Soviet times to the present. The exact share of gross domestic product (GDP) devoted to the military in the USSR was, and remains, a contested issue, with a wide range of estimates, all high by international standards in the post-1945 world. In the author's own assessment, by the late 1980s it was approximately $15 \%$ (see Cooper, 1998, p. 246). In the same year the military share of GDP in the USA was 5.8\% (Deger and Sen, 1991, p. 174). The USSR had a vast defence industry employing more than 8 million people (6 million in RSFSR), including almost 1.5 million in research and development (R\&D) (1.3 million in RSFSR), accounting for almost a fifth of total industrial employment. The defence sector was granted top priority in resource allocation in the planned economy and its personnel enjoyed relatively high monetary, and non-monetary, reward.

With the collapse of the USSR, communist rule and the planned economy at the end of 1991 the situation rapidly changed. With trubled transition to the market the Russian economy contracted sharply and the military began to be starved of resources and, as a consequence, the defence industry, deprived of orders, began to shrink, being kept alive mainly by obtaining a few export orders (see Cooper, 2013, pp. 98-107). By 1997 military spending was only 4.3\% of GDP and defence industry employment had fallen to 2.8 million, including 600,000 in $\mathrm{R} \& \mathrm{D}$, i.e. a contraction to less than half its former scale. ${ }^{1}$ The armed forces, in an increasingly demoralised state, received hardly any new weapons. For some among the country's leadership this was a humiliation. True, the former superpower still retained nuclear weapons, but its conventionally armed forces were weak and this gave rise to a deepening sense of insecurity. This sense was heightened in 1998 when the already fragile economy experienced a serious financial crisis. Output contracted sharply and military spending fell to 3\% of GDP.

With Vladimir Putin as president from May 2000, aided by pro-market reforms and rising prices of oil and natural gas, the country's principal exports, the economy revived and there began almost a decade of growth of GDP at an annual average rate of almost 7\%. Government finances strengthened and it became possible to spend more on defence. However, the government was committed to macroeconomic stability and the share of spending on the budget chapter "national defence", financing the Ministry of Defence (MOD) armed forces, was held stable at approximately $2.5 \%$ of GDP. This improved conditions and morale in the military but was not enough to fund any meaningful re-equipment with new armaments and other military hardware. The country was regaining economic strength but militarily was weak, with armed forces attempting to cope with increasingly aged weaponry dating back in the main to the 1980 s or earlier. A sense of resentment began to mount, a feeling that in less than twenty years a once great power had suffered a humiliating loss of strength and influence on the world stage. By the mid-2000s there was a growing body of opinion that the West was at least partly to blame for this state of affairs, perceived to be acting

\footnotetext{
${ }^{1}$ SIPRI military expenditure database, http://www.sipri.org/research/armaments/milex/research/armaments/ milex/research/armaments/milex/milex_database; Cooper (2013, p. 102).
} 
as winners of the Cold War, preferring to deal with a weakened Russia. It was this sentiment that President Putin voiced in his tough speech at the Munich security conference in February 2007, when he railed against the "unipolar" world, in retrospect a harbinger of Militant Russia.

It was the brief war with Georgia in August 2008 that convinced Russia's leadership that reform and re-equipment of the armed forces could no longer be postponed. A new civilian defence minister, Anatolii Serdyukov, was appointed, and with the full backing of President Dmitrii Medvedev and prime minister Putin, he pushed through a set of far-reaching, controversial, but over-due, reforms. ${ }^{2}$ Prior to the onset of the 2008-2009 global financial-economic crisis, a ten-year forecast was approved, envisaging economic growth at an annual average rate of approximately $6 \%$. On the basis of this optimistic scenario, a new state armament programme was elaborated for the period 2011 to 2020, signed into action by Medvedev on the final day of 2010. It is the implementation of this highly ambitious programme, envisioning the spending of 20.7 trillion rubles (at the exchange rate when it was adopted, \$680bn) over ten years, that has been the principal driver of the rapid growth of military expenditure in Russia over the past five years.

As shown in Fig. 1, military spending on the armed forces of the MOD has increased rapidly as a share of GDP since 2012 , from just under $3 \%$, to $3.5 \%$ in 2014 and $4.4 \%$ in the 2015, falling back to $4.0 \%$ in the 2016 federal budget.

However, this understates the actual volume of military expenditure in Russia. In addition to spending on the MOD forces, under other chapters of the budget there is spending on the internal troops of the Ministry of the Interior, the border troops of the Federal Security Service, additional spending of the MOD shown under a number of budget chapters, including "housing", "education", "health", "social policy", "culture" and "sport", and financial support for "closed" cities of the MOD and the nuclear weapons industry under the "Rosatom" state corporation. Total military spending as a share of GDP is shown in Fig. 2.

It can be seen that by 2014 the share had reached $4.5 \%$ of GDP, very high by international standards, and almost 5.5\% in 2015. This puts Russia in a limited

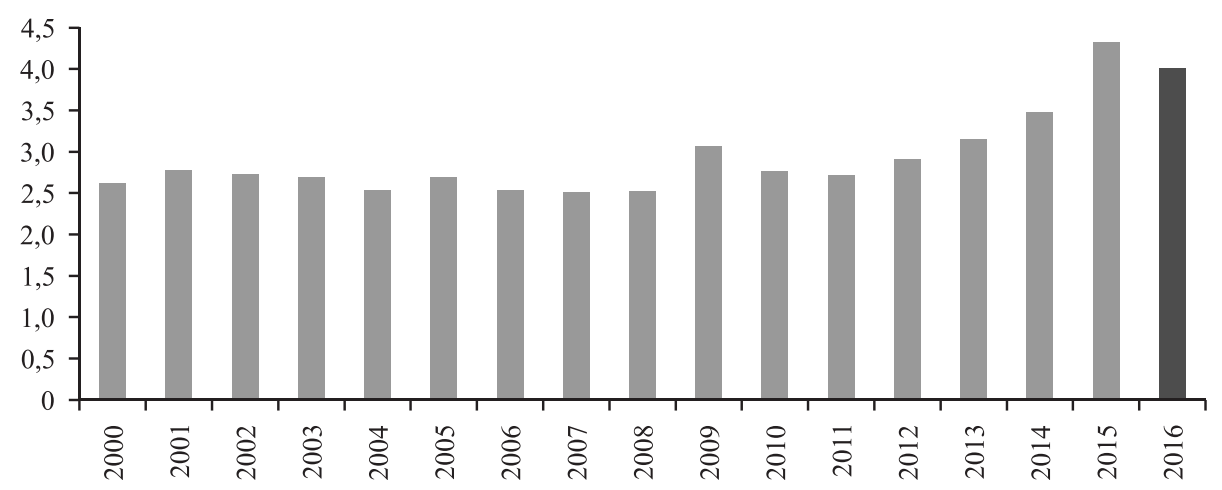

Fig. 1. Spending on "national defence" as a \% of GDP, 2000-2015: actual spending, 2000-2015; federal budget, 2016.

Note: The fall in GDP with the global financial-economic crisis accounts for the spike in 2009. Source: Cooper (2015, 2016a).

${ }^{2}$ On the Serdyukov reforms, see Klein (2012) and Renz (2014). 


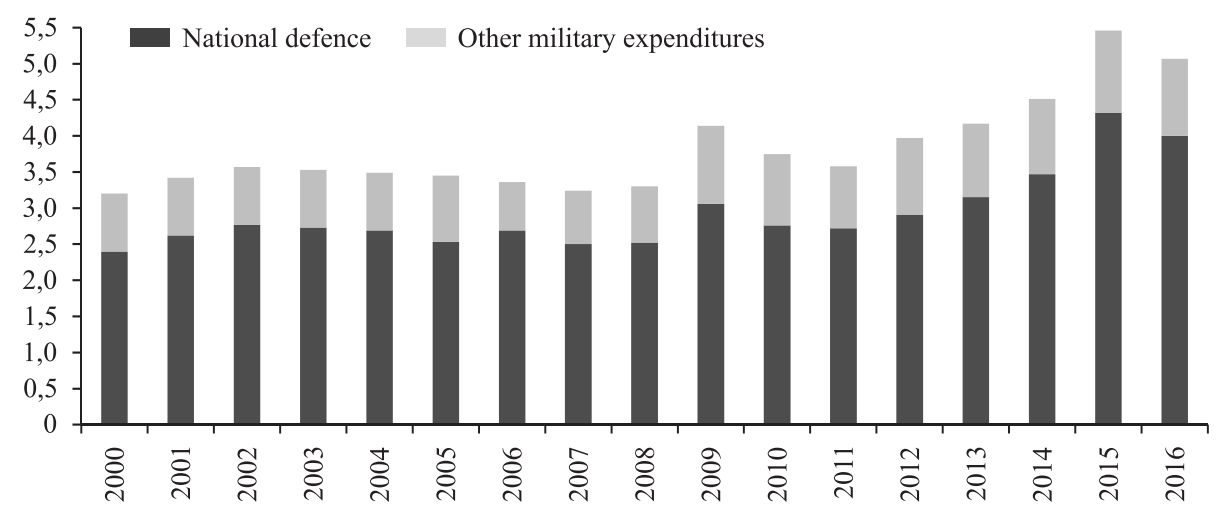

Fig. 2. Total military spending of Russia as a \% of GDP, 2000-2016 federal budget Source: Cooper (2015, 2016a).

group of countries devoting in excess of 5\% of GDP to defence. In 2014, according to the Stockholm International Peace Research Institute (SIPRI), there were only nine such countries, all in Africa and the Middle East. In that year the USA allocated 3.5\% of GDP, both France and Germany - 2.2\% and China- $2.1 \%$. However, if Russian military spending is considered in dollar terms, the magnitude of the commitment can be seen better in comparative terms. According to SIPRI, in current US dollar terms Russia spent $\$ 84.5$ bn on defence, compared with the USA \$610bn, China \$215bn, France \$63.3bn and the UK \$60.5bn rising to third largest spender, compared with fifth in 2009. ${ }^{3}$ However, it should be noted that the average 2014 ruble/dollar exchange rate was relatively favourable to Russia; with the sharp depreciation of the ruble in late 2014 and 2015 defence spending in current dollar terms appears less impressive. ${ }^{4}$

As noted above, the principal factor responsible for this rapid increase in spending has been the re-equipment and modernisation of the armed forces although there have also been pay increases and higher spending on training, exercises and other aspects of operations and maintenance. The annual stare defence order, based on the provisions of the state armament programme, covers the procurement of new armaments and other military hardware, the repair and modernisation of existing armaments, and defence-related R\&D. Fig. 3 shows the rapid growth in recent years of the share of total spending on "national defence" accounted for by the MOD's annual state defence order.

Notwithstanding mounting economic problems the $60 \%$ share envisaged in the 2015 budget and the sharp increase over the level of 2014 were in fact realised. This reflects a very determined commitment by the top civil and military leadership, in the spirit of Militant Russia, to implement the armament programme as fully as possible notwithstanding the economic performance far less favourable than envisaged when the programme was drawn up. Indeed, the state of the economy was deteriorating further before the budget was signed

\footnotetext{
${ }^{3}$ http://www.sipri.org/research/armaments/milex/research/armaments/milex/research/armaments/milex/ milex_database.

${ }^{4}$ The average ruble to the dollar exchange rate in 2014 was 38.0 ; in January-July 2015 - 57.2 (http://www. eeg.ru/pages/22).
} 


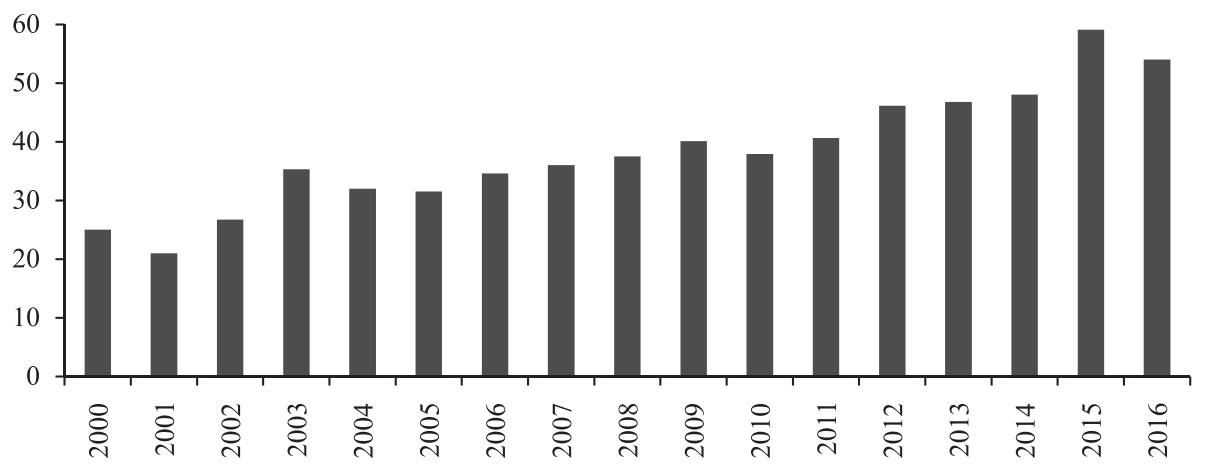

Fig. 3. Spending on the annual state defence order of the MOD as a $\%$ of spending on "national defence", 2000-2016 federal budget

Source: Cooper (2015, 2016a).

into law in late 2014. As discussed below, while the 2015 budget was being implemented it became clear to the government that the pace of military modernisation would have to be moderated.

\section{Rearming Russia}

The implementation of the state armament programme to 2020 (hereafter GPV-2020) has not been without problems, including disputes over the prices of new armaments and delays in the realisation of major new projects, but over its first five years secured a significant renewal of the equipment of the armed forces. Between 2011 and 2015 the strategic missile forces received approximately 70 ICBMs, including 58 new "Yars" (RS-24) systems. Two development programmes for new systems are proceeding as scheduled, the "Sarmat" heavy liquid-fuelled missile and the "Barguzin" rail-based launcher, which will carry the "Yars". The air force and navy obtained almost 330 new fixed wing aircraft, including more than 225 combat planes, and over 500 helicopters, including approximately $160 \mathrm{Ka}-52$ and Mi-28N attack helicopters. The air and space defence forces received 15-20 division sets of advance S-400 "Triumf" air defence systems and several new "Voronezh" radars for the country's ground based missile early warning system. The re-equipment of the ground forces was less impressive, to a large extent because efforts were focused on major development programmes to create three original "platforms" for a new main battle tank (the "Armata"), tracked armoured vehicles (the "Kurganets") and wheeled armoured vehicles (the "Bumerang"). While awaiting these new systems the ground forces received in the main modernised variants of existing armaments dating back to Soviet times. However, the procurement of one major item of equipment, the "Iskander" tactical missile system, is on schedule in accordance with GPV-2020. The navy has an ambitious renewal programme but its implementation has been slower than planned. Three new "Borei" class strategic submarines were handed over, each armed with the new "Bulava" missile system, one new "Yasen" class multi-role nuclear submarine and three "Varshavyanka" diesel-electric submarines. Meanwhile, older strategic submarines have been refitted with the latest "Sineva" and "Lainer" versions of an established, proven 
missile. No large surface ships were procured, but the fleet was supplemented by three-four new corvettes and two frigates. What would have been Russia's largest purchase of military equipment from abroad, the delivery by France of two "Mistral" class helicopter-carrying assault vessels, was hit by NATO and EU sanctions and the contract terminated. The goal was to have at least $30 \%$ modern armaments and other military hardware in the forces by the end of 2015 and this was exceeded to quite a large degree (Based on Cooper, 2016b).

However, problems have arisen. The poor state of the economy is leading to some reconsideration of priorities, a number of development programmes are running behind schedule, with rising costs, and, as discussed in the next section, the defence industry is experiencing difficulties arising from a breakdown of military supplies from Ukraine and sanctions imposed by NATO and EU member countries.

\section{The impact of the Ukraine crisis and the policy response}

The end of military supplies from Ukraine, announced in June 2014, has already had an impact on the fulfilment of GPV-2020. With respect to strategic missiles and space systems the evidence to date does not indicate any major problems arising from the breakdown of relations with Ukraine, although Russian specialists are now having to maintain the Soviet-era "Voevoda" (SS-18, "Satan") heavy ICBM, built in Ukraine and formerly maintained by engineers from Dnepropetrovsk. In the aviation industry, the building in Russia of An-140 and An-148 passengertransport planes has been curtailed and the ending of delivery of engines for military helicopters has reduced the volume of their procurement. Engines for Ka-52 and $\mathrm{Mi}-28 \mathrm{~N}$ combat helicopters are now manufactured in Russia but the volume of domestic engine production is not adequate to meet all needs, leading to a sizeable reduction in the state defence order for helicopters in 2015. The naval programme is also being affected. Both the corvette and frigate programmes are being disrupted by the Ukraine crisis, the former by the non-delivery by Germany of diesel power units; the latter by the end of deliveries of gas turbines produced in Ukraine. And, of course, the sale of the two "Mistral" class assault ships fell victim to sanctions.

In response to Russian actions in Ukraine, the USA and other NATO member countries, plus the EU, imposed sanctions intended to strike at Russia's current and future military capability. All arms transfers to Russia were halted; eight named corporations of the Russian defence industry were singled out for action designed to limit cooperation with Western firms and restrict access to finance abroad; and Russia's access to "dual-use" goods was made more difficult, an action reminiscent of the COCOM controls imposed on the USSR during the Cold War. Some of the named corporations have experienced limited financial difficulties and been obliged to end joint activities with firms based in sanctioning countries, but these problems do not appear to have had any impact on their work for the Russian armed forces or arms exports. Depending on the duration of the sanction, limitation of access to dual-use technologies could have a significant impact in the medium to long term, above all in relation to electronic components and advanced production equipment imported for use in the defence industry. There is evidence that in expectation that market conditions could become more difficult enterprises of the radio-electronics industry sharply increased their imports in 2014 , by 2.6 times to $\$ 773$ million, probably to boost stocks of components 
in an attempt to insure against sanctions. The depth of import dependence on Russia's market for radio-electronic products is shown by the industry's target for 2015: to raise the share of domestic production to only $20 \%$, and the share of the world market to a mere $0.5 \% .^{5}$

Import dependence on EU and NATO member countries is especially acute with respect to machine tools and other advanced production equipment. According to the Ministry of Industry and Trade, in 2013 88\% of the machine tool market was taken by imports and the share may be even higher for the defence industry in so far as domestic manufacture tends to focus on equipment not at the frontier in terms of precision and degree of automation. ${ }^{6}$ In recent years there have been efforts to strengthen the domestic production capability in machine tools and tooling. The state corporation "Rostekh" now has control of "Stankoprom" holding company, created in 2013, uniting eight of the country's leading producers and charged by the government with being the systems integrator for the entire Russian machine tool industry. ${ }^{7}$ It has an orientation to securing the needs of the defence industry. However, the modernisation policy entailing in part the creation of joint ventures with foreign partners with sanctions may now be under threat.

The Russian response has been rapid and determined, a concerted drive to secure self-sufficiency by a programme of domestic import substitution and switching to suppliers considered fully dependable, above all in Belarus and other CIS countries, plus manufacturers in China and other Asian economies. The aim is to minimise Russia's exposure to any future sanctions as rapidly as possible. The programme of import substitution in relation to Ukraine, valued at c. 50bn rubles, was approved by Putin in July 2014. It is a detailed, classified, schedule of import substitution activities over a period lasting to 2018 . The programme will be partfunded from the federal budget but a large proportion of the measures will be realised from the resources of enterprises (Barabanov, 2015). It has been claimed that the programme covers more than 3,000 components and systems, produced by over 160 Ukrainian enterprises, entering into more than 200 models of armaments, military and special hardware. ${ }^{8}$

A programme of import substitution measures in response to Western sanctions affecting the defence sector was signed off by the President in January 2015. ${ }^{9}$ Its cost has not been revealed. According to deputy prime minister Dmitrii Rogozin, there are 640 models of armaments and military hardware dependent on component imports from NATO and EU countries and the intention is to substitute the inputs for 571 of them by $2018 .{ }^{10}$ Some positions, he acknowledges, will be difficult to cover, in particular radiation-resistant electronic components for space use and the nuclear industry, and this would take longer. ${ }^{11}$

Clearly, not all inputs currently obtained from NATO and EU member countries will be manufactured in Russia. In some cases, notably for electronic components,

\footnotetext{
${ }^{5}$ http://instel.ru/wp-content/uploads/2015/05/Решение-расширенного-совещания-РЭП-2015-г..pdf.

${ }^{6} \mathrm{http}: / /$ minpromtorg.gov.ru/activities/industry/otrasli/stankostroi/. Import dependence is probably even more pronounced for control systems for numerically controlled machine tools.

${ }^{7} \mathrm{http}: / /$ www.kommersant.ru/doc/2633606.

8 http://izvestia.ru/news/574998.

9 http://www.ng.ru/armies/2015-01-22/2_sanktsii.html.

$10 \mathrm{http} / / /$ www.militarynews.ru/story.asp? $\overline{\mathrm{rid}}=1 \&$ nid=381547.

$11 \mathrm{http}: / /$ ria.ru/defense_safety/20150529/1067144746.html (Rogozin at Vladimir economic forum).
} 
they can be imported from Belarus and Asian economies. In August 2014 it was reported that over the next two-three years while domestic production is being organized on an import substitution basis, China would play a significant role as a source of military and space specification electronic components, with annual imports of at least \$1bn, replacing much of the \$2bn a year previously obtained from the USA. ${ }^{12}$ Also in relation to electronic components there is the issue of redefining what constitutes a "domestic producer" to include some Russian-owned companies abroad and foreign manufacturing facilities working to Russian designs. In the case of production equipment, some can be obtained from China and other non-NATO/EU countries but developing a stronger domestic industry will be difficult without joint ventures with leading world producers. One limiting factor which threatens to make difficult the early realization of import substitution in the machine tool industry is an acute shortage of highly trained, experienced, engineering personnel and shop floor workers (see Kapustin, 2015).

It remains to be seen how these ambitious import substitution programmes will be realised. For the defence industry the sudden turn to a policy of import substitution represents an abrupt reversal of what was becoming a cautious, but steady, move towards more active participation in global defence and high technology networks, an internationalization of a formerly rather closed system. It was believed that this path offered a route towards greater efficiency and competitiveness. There are now fears that the turn to self-reliance, especially if pursued in a politicized, campaign-like, manner, could have negative outcomes (see, e.g. Sinitskiy, 2015).

\section{Economic constraints beginning limit plans}

In the course of 2014 and 2015, with a depressed global economy, the performance of the Russian economy deteriorated under the impact of declining prices for oil and gas, a depreciating currency, inflation, high interest rates, a declining rate of investment and underlying structural problems, not addressed adequately by the government over a number of years. At the same time, the economy was experiencing difficulties created by Western sanctions and the Russian countermeasures, namely banning imports of agricultural products and foodstuffs from sanctioning countries. With an increasingly strained budget situation, it began to be recognised that the growth of military expenditure would have to be moderated. In particular, it was decided to delay the adoption of a new armaments programme to 2025, originally scheduled to begin in January 2016, to 2018. In the meantime, efforts will be focused on the implementation of the current programme to 2020 and the realisation of import substitution programmes. While spending on the armament programme was retained at the 2015 level by resort to additional state guaranteed credits, spending on "national defence" declined from $4.3 \%$ of GDP in 2015 to $4.0 \%$ in 2016 (Cooper, 2016a). It is possible that the military and defence industry interests will lobby successfully for some protection when the budget is amended later in the year but it will probably remain the case that the year 2015 will stand out as an exceptional peak of resource commitment to boosting the country's defences.

\footnotetext{
12 http://izvestia.ru/news/574886. This will involve close cooperation with the China Aerospace Science and Industry Corp, CASIC.
} 


\section{Pivot to the East}

Since the beginning of the Ukraine crisis there has been a rapid development of closer military relations with China and other Asian powers. This is part of general "turn to the East" as Russia weakens relations with the United States, the European Union and other NATO member countries. It is China that has been the main focus of attention, as a rapidly rising global power committed, like Russia, to the development of a more clearly expressed multi-polar international order. Like Russia, China faces attempts by the United States to contain its growing military potential. It also offers increasing possibilities for industrial cooperation as China's scientific and technological capabilities match and in some sectors, notably in electronics, outstrip those of Russia.

The closeness of military relations was demonstrated in May 2015 when President Xi Jinping was guest of honour at Russia's commemoration of the 70th anniversary of the defeat of Nazi Germany and sat next to Putin during the 9 May 2015 military parade, in which a contingent of Chinese troops participated. This was reciprocated in September when Putin was guest of honour at China's military parade to mark the 70th anniversary of the defeat of Japan.

In the 1990s and early 2000s China was one of Russia's largest customers for armaments. Over time, however, China's own industrial capability matured to a significant degree and orders began to decline. Increasingly, China sought Russia's latest, most advanced, weapons but Russia was unwilling to sell as it was feared that they would be copied, leading to the appearance later on the global arms market of Chinese clones at lower prices than the original Russian models. With improved relations this situation began to change: Russia has agreed in principle to sell China two of its most modern weapons, the Su-35S fighter and the S-400 air defence system. Talks on the former began in 2012 but progress was delayed by Russian concerns relating to intellectual property rights, understandable as there is a long history of Chinese "borrowing" of Russian aviation technology, but in the summer of 2015 Rosoboroneksport indicated a contract for the delivery of $24 \mathrm{Su}-35 \mathrm{~s}$ was likely to be signed before the end of the year. ${ }^{13}$ A contract for the supply of the S-400 has yet to be concluded. Again there are copyright fears but on the Russian side also capacity constraints. Domestic procurement of the S-400 has first priority and it is unlikely that China will obtain the system before 2020 at the earliest. Russia and China have also agreed to develop jointly a new heavy-lift helicopter and China is also interested in acquiring the RD-180 rocket engine for use in space launchers. ${ }^{14}$

In May 2015 Russia and China conducted joint naval exercises in the Mediterranean and in August in the Far East, involving vessels of the Russia Far East Fleet and seven ships of the Chinese navy, including a destroyer. ${ }^{15}$ It is likely that more joint military exercises will follow. However, while a full military alliance is not a serious possibility, a pragmatic military partnership of symbolic importance as much as a link promoting real military effectiveness should not be ruled out. For Russia it is a manifestation of the long-sought multi-polarity of the post-

\footnotetext{
13 http://vpk.name/news/134206_rossiya_nadeetsya_podpisat_s_kitaem_kontrakt_po_su35_do_konca_goda.html.

$14 \mathrm{http}: / /$ ria.ru/defense_safety/20150825/1206503956.html.

15 http://ria.ru/analytics/20150820/1197434790.html.
} 
Cold War worlds; for China it improves access to military technologies not yet possessed and provides some tactical benefits at a time when the United States is seeking more overtly to contain the country's rising military power.

China is far from being the only Eastern power with which Russia has military relations. To the fore, by scale of deliveries, 2010-14, were India, China, Vietnam, Indonesia, Myanmar, Bangladesh, Pakistan, Mongolia, Thailand, Malaysia and Laos. Overall, during the same period, Asian countries accounted for $64 \%$ of all Russian arms exports. ${ }^{16}$ In the case of India, there is also joint activity in arms development and production, notably cooperation in the development of a fifth generation fighter and the BrahMos supersonic cruise missile. ${ }^{17}$

Another developing forum of Russian and Chinese cooperation in security matters is the Shanghai Cooperation Organisation (SCO), created in 2001. This is not yet a Eurasian counterpart of NATO but its membership is steadily expanding and there is little doubt that its leaders regard it at least in part as a response to a perceived US and Western hegemony in military and security matters. In 2015, when it held a summit in Ufa, to the core membership of China, Russia, Kazakhstan, Kyrgyzstan, Tajikistan and Uzbekistan it was decided to invite India and Pakistan, both currently with observer status, probably in $2016 .{ }^{18}$ Belarus is to be granted observer status and Armenia, Azerbaijan, Cambodia and Nepal will become new "partners in dialogue". ${ }^{19}$ The longer-term intentions of Russia and China with respect to the SCO are not entirely clear but some members are opposed to it becoming a tighter military grouping, in particular Islam Karimov, president of Uzbekistan, who in Ufa said it is necessary "to rule out any kind of bloc mentality and not turn the SCO into a military and political alliance." ${ }^{20}$ Rather than direct military cooperation, the most developed security work of the SCO is in the field of counter terrorism, through Regional Antiterrorist Structure (RATS), based in Tashkent. A major concern of the SCO is now the regional security situation following the US and NATO withdrawal from Afghanistan. At the Ufa summit Putin made it clear that Russia considered the NATO involvement in Afghanistan a far from positive experience. To some extent, the SCO provides a forum for the expression of sentiments in the spirit of Militant Russia.

\section{New priority for the Arctic}

As Russia's military capability strengthens, the Arctic is increasingly becoming a focus of attention. This is clearly a long-term commitment but is being treated as a matter of some urgency and represents a new phase of Russia's evolving policy for the Far North and the Arctic. ${ }^{21}$ As global warming makes the northern route increasingly navigable and hydrocarbons extraction moves northward,

\footnotetext{
${ }^{16}$ Calculated from the arms transfers database of SIPRI, http://www.sipri.org/databases/armstransfers.

17 On the BrahMos, see http://militaryrussia.ru/blog/index-445.html.

18 Iran and Mongolia are observer members, Belarus, Sri Lanka and Turkey "partners in dialogue". http:// www.infoshos.ru/en/. Iran applied for full membership in 2008 but according to the rules of the SCO a country subject to UN sanctions cannot become a full member.

19 http://www.rferl.org/content/russia-putin-shanghai-cooperation-organization-summit-brics-ufa/27120442. html (After BRICS, Putin Hosts Shanghai Cooperation Organization Summit in Ufa).

${ }^{20}$ Ibid. As it happens, the next SCO summit will be held in Tashkent in September 2016.

21 For an overview of policy, see Laruelle (2013).
} 
Russia seems determined to defend its territorial interests in the expectation that national rivalries in the Arctic will become more acute.

In December 2014 a new Arctic joint command "Sever" was formed, with headquarters in Murmansk. This new command will also have at its disposal, when necessary, forces in the Eastern and Central Military Districts. ${ }^{22}$ Much new military infrastructure is being built in the Arctic, including a number of air fields, scheduled for completion by the end of 2015. There can be no surprise that the Arctic figures prominently in the new version of Russia's maritime doctrine that was signed into operation by President Putin in late July 2015. ${ }^{23}$ The importance of military and security issues in Russia's policy for the north is underlined by the fact that the chair of the newly formed State Commission for the Development of the Arctic is the tough deputy prime minister, deputy chair of the Military-Industrial Commission, Dmitrii Rogozin. The need for a single centre of responsibility for Arctic policy was proposed by President Putin at a meeting of the Security Council in April 2014 and later in the year he spoke of the need to strengthen the defences of the Arctic without its militarisation. ${ }^{24}$ There is no doubt that from now on Russia will be a highly assertive power in all matters concerning the development of the Far North and the necessity for its effective defence.

This more assertive military stance in the north is matched by a less evident but real process of building up the capability in the south, partly through the Collective Security Treaty Organisation (ODKB), which is devoting increasing attention to the level of equipment of the forces of the countries involved and focusing on Central Asia, concerned that the withdrawal of US and other troops from Afghanistan will create security threats to Russia's south. In August 2015, with the aim of strengthening Russia's engagement with the ODKB, Putin decreed the formation of an inter-agency working group, the ten government departments involved including the MOD, FSB, the Ministry of Foreign Affairs and the Federal Service for Military-Technical Cooperation. ${ }^{25}$

\section{Preparing to defend the country}

A significant manifestation of the new assertiveness of Russia is not only the serious efforts to enhance the country's military capability but also the concern to ensure that the nation could respond rapidly and decisively in the event of any external aggression. The Ukraine crisis and the response of the West to the annexation of Crimea and conflict in Eastern Ukraine have generated an enhanced sense of vulnerability to potentially hostile acts, with the United States perceived as the principal source of danger. Indeed, there are many in Russia who regard the Ukraine conflict as a new form of proxy war, with a belief that US support for Kiev and Ukrainian military action in the East against separatists amounts to indirect US aggression against Russia. Some go as far as to claim that a new world war has actually started, taking new forms, aggression being pursued not

\footnotetext{
22 http://www.mk.ru/politics/2015/07/26/rossiya-narashhivaet-voennuyu-gruppirovku-v-arktike.html.

23 http://www.kremlin.ru/events/president/news/50060; http://static.kremlin.ru/media/events/files/ru/uAFi5nvux2twaqjftS5yrIZUVTJan77L.pdf (The Maritime Doctrine of the Russian Federation).

${ }^{24} \mathrm{http} / / /$ www.kommersant.ru/doc/2661252.

25 http://www.rg.ru/2015/08/22/odkb-site-anons.html.
} 
only through military action, but also by information warfare, sanctions and other economic measures, politics and diplomacy, all amounting to a comprehensive "hybrid" war of a new 21st century nature (Examples include Bartosh, 2015). This view is held in conservative, nationalist, and security-orientated circles, notably by adherents of the Izborskii Club, including such figures as Presidential advisor on Eurasian integration, Sergei Glaziev, retired military leader, Leonid Ivashov, Aleksandr Prokhanov, editor of the weekly Zavtra, and the ideologist of neo-Eurasianism, Aleksandr Dugin. ${ }^{26}$ From the outset, the Izborskii Club, formed in 2012, has taken the view that a major new global conflict is almost inevitable, with Russia the principal target of aggression. In their view, it is imperative that Russia adopts a "great breakthrough" strategy, a mobilisation project, to prepare the country for this "highly probable" great war, forecast, in their manifesto of October 2012, to occur within 7-10 years (Averiyanov et al., 2013, p. 51). ${ }^{27}$ While this may be the view of an ideologically committed minority, the belief that Russia must be better prepared for possible external aggression appears to be widely held in military and security circles.

This perception of Russia being the potential victim of aggression has been heightened by military developments in the West, in particular discussion in the USA of a so-called Prompt Global Strike, efforts to develop a capability to deliver a precision-guided conventional airstrike anywhere in the world within one hour. This development has been followed very closely in Russia and some recent arms procurement decisions have clearly been influenced by it. For Russia it is to be countered by upgrading the country's nuclear capability, in particular by the development of the new heavy multiple-warhead "Sarmat" ICBM and the rail-based "Barguzin" missile system, the future deployment of the S-500 air and space defence system, and by improving the military's missile early warning capability and reducing the response time in the event of any perceived attack. In addition, serious efforts have been made to enhance the central coordination of the armed forces and secure a more rapid, concerted, response in the event of armed conflict.

\section{The National Defense Management Center}

One significant manifestation of this concern to improve the country's ability to respond to external threats is the creation in less than a year, as a matter of highest state priority, of the National Defense Management Center of the Russian Federation (known in Russian as NTsUO). Part of the MOD's complex on the Frunze Embankment, its total cost was reported to be almost 40bn rubles, at the time equivalent to $\$$ US $1.2 \mathrm{bn}^{28}$

The NTsUO does not yet exist in a developed working form and the full networked, inter-agency, coordination remains an aspiration. According to one

\footnotetext{
26 Thus Dugin, in August 2014, “...it is necessary to acknowledge the fact: in reality we find ourselves in a state of war with the USA and countries of NATO”. http://vk.com/duginag?w=wall18631635_3638. For Glaziev, a fourth world war is already underway (the third being the Cold War), with Russia as the principal target, the United States striving to retain it global dominance (Glaziev, 2015, pp. 12-13). But this is a "hybrid war", not a full military assault. http://www.dynacon.ru/content/articles/6818/.

${ }^{27}$ However, an introductory article gives a timescale of 5-7 years (p. 39).

${ }^{28}$ http://www.trud.ru/index.php/article/21-01-2014/1306228_takimi_kamnjami_ne_brosajutsja.html.
} 
author, the technical facilities of the NTs will "in future" permit the obtaining of information in real time from all parts of the country. ${ }^{29}$ Nevertheless, the creation of the NTsUO is a significant development, tending to confirm that after almost twenty-five years of reduced state priority and under-funding Russia once again possesses a military capability meriting respect. The Moscow centre is now at the heart of an expanding network of defence management centres being created in each of the country's military districts and in major territorial subdivisions within them. There is now a Central regional TsUO in Ekaterinburg covering twentynine subjects of the Federation plus Russian military garrisons in Kazakhstan, Kyrgyzstan and Tajikistan, a Southern regional centre in Rostov-on-Don, and an Eastern centre in Khabarovsk. Territorial centres are also being established, early examples include those of Samara and Novosibirsk. ${ }^{30}$ The intention is to create a nation-wide real-time information system covering all aspects to the country's defence, with the National NTsUO as its central point. Given the vulnerable location of the NTs in central Moscow, it cannot be ruled out that there is also a secret reserve centre for use in the event of a major conflict.

Enhancing the preparedness of the armed forces has clearly been the motivating factor behind the series of military exercises, many at short notice, that have become a feature of life in Russia in recent times. Some have been on a very large scale, such as "Vostok-2014" involving a reported 100,000 troops, but most on a regional or local scale involving a limited number of troops. In 2014 a total of more than 3,500 exercises took place. ${ }^{31}$ All service arms have been involved, often engaged in joint operations. Improved funding of the forces has made possible more active training programmes and more extensive outreach to an extent that has generated concern in the West, especially when strategic bombers and advanced combat aircraft have been involved. In turn, this activity has prompted NATO exercises on mounting scale (see Kearns et al., 2014, 2015a, 2015b). This situation has led to interest in establishing agreed security-enhancing procedures for regulating military exercises and reducing the danger of serious, perhaps very dangerous, incidents (see, in particular, ELN, 2015).

\section{A "threatening period" - mobilising in the expectation that worse could follow}

With the annexation of Crimea and ongoing conflict in Eastern Ukraine, Russia has clearly been in a state of heightened military readiness, exemplified by a succession of surprise military exercises, frequent probing flights near European coasts and to the USA by strategic bombers and other aircraft, the very rapid building and inauguration of the NTsUO, and the active engagement by President Putin in military affairs, with many meetings on arms procurement and other defence matters. This level of activity suggests that over the past year Russia has been effectively at an early stage of its well-established (in Soviet times) procedure of "mobilisation". This is another manifestation of Militant Russia.

\footnotetext{
${ }^{29}$ http://www.mk.ru/politics/2014/10/27/grandioznyy-pereezd-minoborony-vse-idet-po-planu.html.

30 http://www.kommersant.ru/doc/2635458; http://topwar.ru/64895-yuzhnyy-regionalnyy-centr-upravleniyaoboronoy-rossii-zastupil-na-boevoe-dezhurstvo.html; http://baikalfinans.com/lichnyie-dengi/regionalnyiy-tsentrupravleniya-oboronoy-vvo-povyisil-effektivnost-upravleniya-voyskami.html.

${ }^{31}$ http://top.rbc.ru/politics/07/09/2015/55ed3abc9a7947b38cbede6c.
} 
The Russian system of preparing for war and mobilisation of the economy is based on that of the USSR. In a "threatening (ugroshaemyi) period" when armed conflict could appear state agencies are primed to take action and begin to undertake military, economic, diplomatic and informational measures. If the war danger increases a so-called "special (osobyi) period" is notified. During the "special period" steps are taken to mobilise the economy and state institutions so that the country is prepared fully for a declaration of war.

This heightened concern with mobilisation is not new, it predates the Ukraine conflict. In 2010 a "Concept of improving the mobilisation preparation of the Russian economy in present-day conditions" was adopted. ${ }^{32}$ In the following year work began on preparing a new Mobilisation Plan, which as in Soviet times, is done every five years. ${ }^{33}$ Economic aspects of mobilisation are the responsibility of the Military-Industrial Commission, since September 2014 year chaired by Putin. The preparation of control bunkers and other infrastructure for running the country in the event of war is vested with the Main Directorate of Special Programmes (GUSP), the most secretive of all government agencies. Reserve stocks of food, medicines, materials and equipment held for emergencies and war are managed by the Federal Agency for State Reserves, another secretive body. A new feature of this preparation for a possible conflict is that it is now undertaken within the framework of the Plan of Defence.

According to Valerii Gerasimov, chief of the General Staff of the armed forces, a new statute of the Staff was adopted in June 2013, intended to enhance its role in coordinating the work of all federal agencies of executive power in securing the country's defence. ${ }^{34}$ Clearly, the Plan of Defence, also specified in the statute, is one of the instruments for implementing this responsibility. The first such Plan was signed off by Putin in January 2013. ${ }^{35}$ The Plan sets out the tasks of 52 federal agencies plus three state corporations in the field of defence in both peace time and war. $^{36}$ Details are not available, but according to Gerasimov it specified the measures and resources required to "secure in good time the preparation of the country for transition to wartime conditions." 37 A new version of the Plan, for the years 2016 to 2020, was signed off by President Putin in November 2015. ${ }^{38}$ The new NTs can be seen as a logical development of the new role of the General Staff in securing an enhanced, more effective, level of coordination. According to Gerasimov, the need for such timely coordination has become pressing because of changes in the international situation. Conflicts now develop with great rapidity and involve the use of both military and non-military means, and "the reaction time for transition from political and diplomatic measures to the application of military force has been reduced to the maximum." 39

\footnotetext{
32 http://archive.government.ru/eng/docs/9146/ (Sergei Ivanov on the draft Concept, 27 January 2010).

$33 \mathrm{http} / / /$ top.rbc.ru/economics/14/01/2014/899309.shtml.

34 Speech at the annual meeting of the Academy of Military Sciences (VPK, 5 February 2014. http://vpk-news. ru/articles/18998). For new statute of the General Staff, see The Decree of the President of RF, 23 July 2013, No. 631 (http://www.garant.ru/products/ipo/prime/doc/70319514/).

35 http://www.kremlin.ru/news/17385 (meeting of Shoigu with Putin for approval of the plan, 29 January 2013).

36 http://www.kp.ru/daily/26302/3181011/.

37 Speech at the annual meeting, loc. cit.

$38 \mathrm{http} / / / \mathrm{rg} . \mathrm{ru} / 2015 / 11 / 17 /$ plan-site-anons.html.

39 Speech at the annual meeting, loc. cit.
} 
In 2013 the government adopted eight classified decrees setting out the new regime of mobilisation preparation as applied to various sectors of the economy, including the defence industry, production for medical purposes, electric power, transport, communications and agricultural products and food. The number of organisations required to make preparations was reduced sharply compared with earlier practice. A new mobilisation plan for the economy was adopted for the year 2014, the date of approval of this secret document has not been revealed. According to Sergei Khutortsev, director of the government's department for securing the activities of the Military-Industrial Commission, the mobilisation plan, described as the "military-economic basis for the Plan of Defence" of the country, sets out measures to guarantee meeting the needs of the armed forces, the state and population in the event of war. He observes that in elaborating the plan the necessity of securing the technological independence of Russia in the production of strategic and other armaments is taken into account. Reference is also made to the necessity of delivering agricultural produce and foods by domestic producers (Khutortsev, 2013). This hints that even before the Ukraine crisis there were pressures for a greater degree of self-sufficiency in the interests of safeguarding the country's national security.

In early September 2015 Putin ordered a surprise exercise of the forces of the Central military district. But this was more than a test of the readiness of the armed forces, it also involved aspects of the mobilisation system, including GUSP, Rosrezerv and five government departments, including the ministries of health and agriculture. According to Shoigu, the aim was to check "their readiness for fulfilling tasks in conditions of wartime." 40 The message is clear: foreign powers should not be in any doubt, Russia is ready and determined to defend itself.

\section{And the public view?}

A central feature of Militant Russia is the unity of views on basic issues of the country's leadership and a sizeable proportion of the population. This certainly appears to be the case with respect to military and security policy. According to a July 2015 poll by the respected Levada Centre, $53 \%$ of those surveyed agreed with the statement, "we must spend more on defence even if it causes some problems for our economic development", compared with 34\% who disagreed. In May 1998 the balance of opinion was the reverse: 53\% opposed, 35\% agreed. ${ }^{41}$ Is there a perception that the country now has a stronger, more capable, military? A VTsIOM poll, also in July 2015, asked whether it was believed that Russia's military would be capable to defending the country in the event of military threats from other countries. No less than $86 \%$ said "yes", only $10 \%$ "no". This compares with $67 / 27 \%$ in 2007 and $60 / 33 \%$ in $2005 .{ }^{42}$ There is more opinion poll evidence of a similar nature, leaving little doubt that there is broad public support for the policy of strengthening the armed forces and the government's commitment to increased military spending.

\footnotetext{
40 http://function.mil.ru/news_page/country/more.htm?id=12055103@egNews.

$41 \mathrm{http} / / / w w w . l e v a d a . r u / 21-07-2015 /$ ekonomika-i-oborona. In 2015 "don't knows" were 14\%; in 1998 13\%.

42 http://wciom.ru/index.php?id=236\&uid=115308 (VTsIOM - Russian Public Opinion Research Centre). Whereas only $20 \%$ of those asked would want their brother, son, husband or other close relative to serve in the armed forces in 2002, by July 2015 the share had risen to 59\%.
} 


\section{What does it all mean?}

There are clearly longer-term processes in play that help explain enhanced defence and security concerns in Russia from at least the mid-2000s. A perception in leadership circles that the country was being sidelined and contained by the United States and other Western powers steadily gained ground, leading to the evolution of Militant Russia. However, the Ukraine crisis has served to accelerate and intensify the processes already underway. After a dramatic weakening of Russia's economic and military might over 10-15 years from the collapse of communism and the USSR, and a consequential diminution of the former superpower's role in world affairs, the country is back on track to becoming once again not only a strong regional power, but also a weighty actor on the global stage. This newly acquired military capability was demonstrated to the world in unambiguous terms by Russia's intervention in Syria. With greater economic and military strength Russia's leadership now feels able to be more assertive, expecting other major powers to acknowledge and respect the country's interests and concerns.

The eventual settlement of the Ukraine crisis may cool the rhetoric and permit a rebuilding of relationships. But there can be no return to the status quo ante. Militant Russia is here to stay. The US, EU and other powers, including the UK, will have little choice, regardless of current attitudes towards Putin and the regime, but to work towards a new modus vivendi with a stronger, more assertive and demanding Russia, now with a revitalised military capability.

\section{References}

Averiyanov, V. V., et al. (2013). The strategy of great leap. Izborskii klub: Russkie strategii, 1 (1), 46-73 (In Russian).

Barabanov, M. (2015). Reorganization of Russia's MIC after a break up of relations with Ukrainian enterprises. In A. Dubien (Ed.), Russie 2015: Regards de l'Observatoire francorusse (pp. 96-108). Moscow and Paris (In Russian).

Bartosh, A. (2015). Hybrid war in the economic sphere. Nezavisimoe Voennoe Obozrenie, September 4 (In Russian).

Cooper, J. (1998). The military expenditure of the USSR and the Russian Federation. In SIPRI Yearbook 1998: Armaments, disarmament, and international security (pp. 243-259). Oxford: Oxford University Press.

Cooper, J. (2013). From USSR to Russia. The fate of the military economy. In P. Hare, \& G. Turley (Eds.), Handbook of the economics and political economy of transition (pp. 98-107). London and New York: Routledge.

Cooper, J. (2015). Military spending in the draft law amending the Russian 2015 federal budget: A research note. Available at: http:/www.sipri.org/research/armaments/milex/publications/ unpubl_milex/military-spending-in-the-draft-law-amending-the-russian-2015-federal-budgetresearch-note-april-2015.

Cooper, J. (2016a). Russia military expenditure, 2014, 2015 and 2016 federal budget: A research note. Available at: http://www.sipri.org/research/armaments/milex/publications/unpubl_milex/ russian-military-expenditure-2014-2015-and-2016-federal-budget-a-research-note-researchnote-10-february-2016.

Cooper, J. (2016b). Russia's state armament programme to 2020: A quantitative assessment of implementation 2011-2015 (FOI Report, FOI-R-4239-S). Stockholm: Totalförsvarets forskningsinstitut.

Deger, S., \& Sen, S. (1991). Tables of world military expenditure, 1981-90. In SIPRI Yearbook 1991: World armaments and disarmament (pp. 164-178). Oxford: Oxford University Press. 
ELN (2015). Avoiding war in Europe: How to reduce the risk of a military encounter between Russia and NATO. European Leadership Network, 26 August.

Glaziev, S. (2015). The Ukrainian catastrophe: From American aggression to the World War? Moscow: Knizhnyi Mir (In Russian).

Kapustin, P. (2015). Who will save Russian machine-tool industry? Novyi Oboronnyi Zakaz, 4, 24-25 (In Russian).

Kearns, I., Kulesa, Ł., \& Frear, Th. (2014). Dangerous brinkmanship: Close military encounters between Russia and the West in 2014. European Leadership Network Policy brief.

Kearns, I., Kulesa, Ł., \& Frear, Th. (2015a). Russia-West dangerous brinkmanship continues. European Leadership Network, 12 March.

Kearns, I., Kulesa, Ł., \& Frear, Th. (2015b). Preparing for the worst: Are Russian and NATO military exercises making war in Europe more likely? European Leadership Network, 12 August.

Khutortsev, S. (2013). Mobilization plan of the economy of the Russian Federation - The most important part of the Plan of Defence of the Russian Federation. In Federal reference book. Defense-industrial complex of Russia (vol. 10, pp. 143-146). Moscow: Center for Strategic Programs (In Russian).

Klein, M. (2012). Towards a "new look" of the Russian armed forces? Organizational and personnel changes. In R. N. McDermott, B. Nygren, \& C. Vendil Palin (Eds.), The Russian armed forces in transition (pp. 29-48). London and New York: Routledge.

Laruelle, M. (2013). Russia's Arctic strategies and the future of the Far North. London and New York: Routledge.

Renz, B. (2014). Russian military capabilities after 20 years of reform. Survival, 56 (3), 61-84.

Sinitskiy, A. (2015). Import substitution instead of export orientation. Aviatransportnoe Obozrenie, 160 (In Russian). 